\section{ESTUDO DE VARIÁVEIS QUE PODEM INFLUENCIAR NA EVOLUÇÃO DA FORMA HEPATOESPLENNICA DA ESQUISTOSSOMOSE: EFEITO DA TERAPÊUTICA ESPECÍFICA E DA INTERRUPÇÃO DA
TRANSMISSÃOO}

O desenvolvimento da forma hepatoesplênica da esquistossomose mansônica, ainda não foi completamente esclarecido. Geralmente são invocadas a intensidade da carga parasitária, as reinfecções sucessivas ou periódicas, a resposta imunológica do hospedeiro, a raça e a terapêutica específica, como fatores marcantes para explicar a razâo pela qual, somente pequeno percentual dos parasitados desenvolve essa forma da doença. O presente trabalho faz parte do "Projeto sobre Esquistossomose na Chapada Diamantina - Bahia - Brasil", tendo como objetivo contribuir para o conhecimento do papel das variáveis intensidade da carga parasitária, reinfecções sucessivas, terapêutica específica e raça, no desenvolvimento da forma hepatoesplênica, por ser esta, a mais frequente das formas graves da doença. Um programa de controle da esquistossomose foi desenvolvido em uma área hiperendêmica de esquistossomose, através do uso de moluscicida durante dez anos, com a ajuda da comunidade local. Exames clínicos e parasitológicos de fezes foram realizados antes, durante o período de interrupção da transmissão e após o retorno da transmissão da parasitose. Ao longo dos quinze anos de seguimento dessa população, algumas pessoas fizeram uso de medicaçào anti-esquistossomótica, por demanda espontânea e outras não. A avaliação parasitológica foi feita através os exames de fezes qualitativo e quantitativo, determinando a prevalência e a intensidade da carga parasitária, pelo número de ovos eliminados nas fezes e sua média geométrica. A avaliação da evolução clínica foi feita pela análise do tamanho do fígado e do baço, e pela classificação das formas clínicas, comparando-se o exame inicial com os exames subsequentes. Os principais parâmetros clínicos de evolução - hepatomegalia, esplenomegalia e

Recebido para publicação em 25/05/96.

\section{STUDY OF VARIABLES THAT MAY INFLUENCE ONTHE EVOLUTION OFTHE HEPATOSPLENIC FORM OF SCHISTOSOMIASIS MANSONI: EFFECT OF SPECIFIC THERAPY AND INTERRUPTION OFTHE TRANSMISSION}

The development of the hepatosplenic form of Schistosomiasis mansoni is not completely clear as yet. Intensity of worm load, sucessive or periodic reinfections, immune response of the host, race and specific therapy have been searched as important factors to explain in because some infected individuals develops such form of the disease. This paper is a part of the "Project on Schistosomiasis in Chapada Diamantina - Bahia - Brazil", designed to contribute for the understanding of the role of worm burden, reinfections, specific treatment and race in the development of the hepatosplenic form of Schistosomiasis mansoni, considering that it is the most frequent severe presentation of the disease. A program of the disease control in a hyperendemic area, using moluscicides and local people was undertaken for ten years. Clinical and parasitological examinations were conducted during the non-transmission period and after transmission has returned. During a 15 years follow-up, some patients received specific treatment for their own decision. Parasitological evaluation was performed by qualitative and quantitative stool examinations, through analysis of prevalence and intensity of worm load based upon the number of eggs eliminated in feces and its geometrical mean rate. Clinical evaluation was based on liver and spleen sizes and by classification of clinical forms, comparing the initial and the subsequent physical examination. The principal clinical parameters - hepatomegaly, splenomegaly and hepatosplenic form - were analysed in relation to the total population and in relation to specific therapy. In each situation, data were analysed according to age and race. The processing and analysis of the results were accomplised in accordance to the most appropriated statistical method for each case, using adequated statistical package and considering as significant the finding of $\mathrm{p}$ minor than 0.05 . The results confirm that worm load is directly relates to the development of the 
Resumo de Tese. Bina JC. Estudo de variáveis que podem influenciar na evolução da forma bepatoesplênica da esquistossomose: efeito da terapêutica específica e da interrupção da transmissão. Revista da Sociedade Brasileira de Medicina Tropical 29:629-630, nov-dez, 1996.

forma hepatoesplênica - foram analisados em relação à população geral e ao tratamento específico. Em cada uma dessas situações, os dados foram analisados de acordo com a idade e a raça. O processamento e a análise dos dados foram feitos de acordo com o modelo estatístico mais apropriado para determinado caso, utilizando-se pacotes estatísticos adequados e considerando-se como significante o encontro de $\mathrm{p}$ menor que 0,05 . Os resultados obtidos permitem confirmar que a intensidade da carga parasitária está diretamente relacionada com o desenvolvimento da forma hepatoesplênica $e$ que o grupo racial negro apresenta maior resistência a desenvolver esta forma clínica da doença do que os demais grupos raciais. Além disso, os resultados sugerem que as reinfecções sucessivas e a terapêutica específica são variâveis que influem no desenvolvimento da forma hepatoesplênica da esquistossomose mansônica. hepatosplenic form and the negroes show greater resistance to develop such clinical form of the disease than other racial groups. Furthermore, the results suggest that successive reinfections and specific therapy are variables that influence the development of the hepatosplenic form of Schistosomiasis mansoni.

\section{José Carlos Bina}

Tese apresentada à Faculdade de Medicina da Universidade Federal da Bahia para obtenção do Título de Doutor. Salvador, BA, Brasil, 1995. 